\title{
Social Security Status of HIV-Patients in Brazil \\ COMUE:BAREY
}

Emidio Macedo Lemos Filho1, Tibério Múcio Álvares Cabral Beserra², Antônio de Luna Machado Neto1, Jucier Gonçalves Júnior ${ }^{3}$, Francisco de Castro Júnior ${ }^{1}$, Raimundo Tavares de Luna Neto ${ }^{4}$, Natália Bastos Ferreira4, Alessandro Adamo Gonçalves Oliveira4, Sidney Medeiros de Oliveira4, Jesus de Sousa Cartaxo ${ }^{4}$, Modesto Leite Rolim-Neto1,3,4, Cícera Janielly de Matos Cassiano1, Vânia Barbosa do Nascimento 4

\section{Abstract}

The studies show that HIVIAIDS disease had and is having a high impact on Populations' health but it represents serious socioeconomic problems added for individuals, families, communities and Governments of many countries. In Brazil, the National Standardization Panel of the Federal Courts, the body that comprises the Brazilian National Council of Justice, drafted the docket 78. From this docket, to grant or deny the social security benefit, the judges will not have their decisions limited only to the clinical aspects of medical experts report, starting to also consider the personal, economic, social and cultural aspects of the HIV patient. By analyzing the cases heard by Federal Court of the $5^{\text {th }}$ Region, which constitutes the Brazilian states of Paraíba, Pernambuco, Rio Grande do Norte, Ceará, Alagoas and Sergipe, fourteen cases were found on appeal of special courts. Within those cases, ten were founded to be HIV positive and were granted some sort of pension and welfare benefit, and four were rejected, denying incoming thus those patients with syndrome, the right to receive benefits. The Brazilian Federal Government through the Provisional Measure no 664 from 2014 excluded the art. 151 of the Federal Law 8. 213/91 which dealt with the granting sickness benefit and disability retirement to patients with various disabling conditions which among the HIV saving a total of 18 million to public coffers. The authors point out that the exclusion or this article constitutes the loss of benefits -sickness assistance and disability retirement- those who do not have a minimum period of contribution to Social Security. That constitutes prejudice to the HIV patient's rights in relation helpless leaving them to State coverage. In this context HIV/AIDS diagnosis not only adversely affects individual health and survival but may be associated with higher also need for care, thus resulting in higher expenses for the healthcare system.
1 Faculty of Medicine, Estácio -FMJ, Juazeiro do Norte, Ceará, Brazil.

2 Regional University of Cariri - URCA, Crato, Ceará, Brazil.

3 Faculty of Medicine, Federal University of Cariri-UFCA, Barbalha, Ceará, Brazil.

4 Postgraduate Program in Health Sciences, FMABC, Santo Andre, Sao Paulo, Brazil.

\section{Contact information:}

Jucier Gonçalves Júnior.

Tel: (055) (88)99176746

Address: 284, Divine Savior Street, Downtown, Barbalha, Ceará, Brazil, 63180000 .

ఏ juciergjunior@hotmail.com

Keywords

HIV; Law; Social support. 
An estimated 34 million people are infected with Human Immunodeficiency Virus (HIV) worldwide [1]. There are 1. 1 million HIV-positive individuals living in the Unites States [2] and of nine countries where HIV incidence increased by more than 25\% between 2001 and 2011, six are in eastern Europe and central Asia [3]. In the year 2012, 39,185 cases of AIDS were reported in Brazil. The national average was 20. 2 cases per 100, 000 inhabitants, to which in the last 10 years the country has suffered an increase of about $2 \%$ in the rates of seropositive patients [4].

At the same time, the cost of antiretroviral therapy has gradually increased from about €92 million in 2004 to more than €193 in 2010 as Italian study [5]. In Spain, the estimated treatment cost per patient-year is $€ 11,638$, with an SD of $€ 3,756$. The approximate annual cost of treating these patients in Germany is $€ 32,110$ (SD €6,960). For France, the estimated per-person annual treatment cost is $€ 14,821$ (SD $€ 1,897$ ). Lastly, it was found that the mean cost of this treatment per patient-year in the United Kingdom was $€ 25,340$ (SD $€ 14,549$ ) [6]. In Brazil, between the years of 2005 and 2013, the access to treatment has been increased from 165, 000 (2005) to 400,000 (2014) treated patients, with the prospect of R \$36 million invested in 2014 [7].

Several studies have documented the complex relation between socioeconomic context and the spread of infectious diseases [8]. Deleterious economic effects of HIVIAIDS on individuals and households include reduced income, reallocation and consumption of assets, savings and resources [9]. Its management involves the treatment of AIDSassociated symptoms and opportunistic infections, and other costs associated with morbidity/premature mortality of adult working patients [10].

The National Standardization Panel of the Federal Courts, the body that comprises the Brazilian National Council of Justice, drafted the docket 78. Thus, to grant or deny the social security benefit, the judges will not have their decisions limited only to the clinical aspects of medical report experts, starting to also consider the personal, economic, social and cultural aspects of the HIV patient [11, 12].

By analyzing the cases heard by the Federal Court of the 5th Region, which constitutes the Brazilian states of Paraíba, Pernambuco, Rio Grande do Norte, Ceará, Alagoas and Sergipe, fourteen cases were found on appeal of special courts [13]. Within those cases, 10 were founded to be HIV positive and were granted some sort of pension and welfare benefit, and 04 were rejected, thus denying those patients with the syndrome, the right to receive benefits (Table 1).

It is noteworthy that most of the favorable decisions were based on the fact that the State has the duty to seek public policies that guarantee survival for patients with diseases, not only with medical help, but social support, ensuring a minimum of dignity to the HIV-positive patient, according to the prerogatives of Article 5 of the Constitution of 1988 [14]. Thereby, the HIV/AIDS disease not only had and is having a high impact on populations' health but it represents serious added socioeconomic problems for individuals, families, communities and governments of many countries [15].

The rejected cases were based on expert medical reports from the National Institute of Social Security, which show that the AIDS generates discomfort and some limitations, but not significantly reflected in the performance of normal work activities, not demonstrating any physical or mental disability for independent living or to work. According to literature for the positive HIV worker, physical and psychological issues, like fatigue and cognitive impairment are a problem for optimal functioning at work [16]. Stigma and discrimination also seem to be the main employment-related problems for people with HIV [17].

Another justification for the invalid cases heard is that there is no emergence of occupational diseases that render impossible to work or simply that certain activities that have greater contact with people 
Table 1. Judged proceeding relating to the application for receiving social security benefits from 2012 to 2014 the Regional Federal Court (Tribunal Regional Federal-TRF), 5 ${ }^{\text {th }}$ Region.

\begin{tabular}{|c|c|c|c|c|c|}
\hline Case Number & $\begin{array}{c}\text { Year of } \\
\text { Publishing }\end{array}$ & Comorbidities & $\begin{array}{l}\text { Social-Economic } \\
\text { and social-cultural } \\
\text { conditions }\end{array}$ & Benefits & $\begin{array}{c}\text { Trial } \\
\text { Result }\end{array}$ \\
\hline $\begin{array}{c}0505644-08.2014 .4 . \\
05.8500\end{array}$ & NOV/12/2014 & $\begin{array}{l}\text { injury caused by a shot } \\
\text { in the foot. }\end{array}$ & - & $\begin{array}{l}\text { Sickness } \\
\text { allowance }\end{array}$ & rejected \\
\hline $\begin{array}{c}0519757-10.2013 .4 . \\
05.8400\end{array}$ & MAY/14/2015 & lumbar herniated disc & - & $\begin{array}{l}\text { Sickness } \\
\text { allowance/ } \\
\text { retirement }\end{array}$ & rejected \\
\hline $\begin{array}{c}05006248-03.2013 .4 . \\
05.8500\end{array}$ & FEB/28/2014 & Thrombosis & Low income & OLSA* & favored \\
\hline $\begin{array}{c}0503778-82.2011 .4 . \\
05.8107\end{array}$ & AUG/08/2013 & $\begin{array}{l}\text { Chronic diarrhea and } \\
\text { papular desquamating } \\
\text { lesions }\end{array}$ & $\begin{array}{l}\text { 50-year-old famer/sun } \\
\text { exposure }\end{array}$ & $\begin{array}{l}\text { disability } \\
\text { retirement }\end{array}$ & favored \\
\hline $\begin{array}{c}0508532-76.2011 .4 . \\
05.8201\end{array}$ & JUL/12/2013 & $\begin{array}{l}\text { Diabetes mellitus; } \\
\text { leprosy }\end{array}$ & $\begin{array}{c}46 \text { years old; } \\
\text { Low level of education; } \\
\text { farmer; } \\
\text { general services }\end{array}$ & OLSA & favored \\
\hline $\begin{array}{c}0504478-75.2008 .4 . \\
05.8103\end{array}$ & MAY/09/2013 & - & $\begin{array}{l}\text { Faces prejudice for having } \\
\text { AIDS, small town }\end{array}$ & $\begin{array}{l}\text { Sickness } \\
\text { allowance }\end{array}$ & favored \\
\hline $\begin{array}{c}0521906-61.2008 .4 . \\
05.8300\end{array}$ & APR/24/2013 & - & $\begin{array}{l}\text { Low income; } \\
\text { No education level; } \\
51 \text { years old. }\end{array}$ & $\begin{array}{l}\text { disability } \\
\text { retirement }\end{array}$ & favored \\
\hline $\begin{array}{c}0500869-18.2012 .4 . \\
05.8403\end{array}$ & MAR/20/2013 & pulmonary tuberculosis & - & $\begin{array}{l}\text { disability } \\
\text { retirement }\end{array}$ & favored \\
\hline $\begin{array}{c}050302-58.2012 .4 . \\
05.8501\end{array}$ & JAN/11/2013 & $\begin{array}{l}\text { Fever; } \\
\text { Diarrhea. }\end{array}$ & $\begin{array}{l}\text { Faces prejudice for having } \\
\text { AIDS, small town }\end{array}$ & OLSA & favored \\
\hline $\begin{array}{c}0516526-52.2011 .4 . \\
05.8300\end{array}$ & OCT/29/2012 & $\begin{array}{c}\text { Kaposi's sarcoma and } \\
\text { rheumatic mitral valve } \\
\text { disease }\end{array}$ & Low education level & $\begin{array}{l}\text { Sickness } \\
\text { allowance }\end{array}$ & favored \\
\hline $\begin{array}{c}0500520-09.2012 .4 . \\
05.8502\end{array}$ & SEP/21/2012 & - & Below poverty line & OLSA & Favored \\
\hline $\begin{array}{c}\text { 0504397-08. } 2008.4 . \\
05.8401\end{array}$ & JUL/27/2012 & - & $\begin{array}{c}\text { Advanced age, } \\
\text { low education and social } \\
\text { situation }\end{array}$ & $\begin{array}{l}\text { Disability } \\
\text { retirement }\end{array}$ & favored \\
\hline $\begin{array}{c}0500012-26.2012 .4 . \\
05.9840\end{array}$ & $\mathrm{FEB} / 24 / 2012$ & - & - & & \\
\hline $\begin{array}{c}0503262-44.2011 .4 . \\
05.8501\end{array}$ & FEB/03/2012 & - & driver & $\begin{array}{l}\text { Sickness } \\
\text { allowance }\end{array}$ & rejected \\
\hline
\end{tabular}


generates greater presence of prejudice and discrimination. Literature argues that persons with severe mental illness (SMI) have high rates of HIV-riskrelated behaviors [18]. Major depression is highly prevalent among HIV-positive patients [19].

The Brazilian Federal Government through Provisional Measure number 664 in 2014 excluded the art. 151 of the Federal Law 8. 213/91 which dealt with the granting of sickness allowance and disability retirement to patients with various disabling conditions among which HIV [20] saving a total of 18 million to public funds. The exclusion of this article constitutes a loss of benefits -sickness allowance and disability retirement- for those who do not have a minimum period of contribution to Social Security. This is prejudice to the right of HIV patients, leaving them helpless in relation to state coverage. In this context HIVIAIDS diagnosis not only adversely affects individual health and survival but may also be associated with higher need for care, thus resulting in higher expenses for the healthcare system [21].

Therefore, the pension system being contributory, there is no way to be disengaged from the social, economic and cultural reality of the country, where social problems require the law to shape up and reinvent itself to meet the demands of the population. In the context of Social Security Law, the docket 78 of the National Standardization Panel innovates by showing that the increased support to HIV-positive patient promoted by State should be a priority, especially when considering the individual socioeconomic spheres. This brief also points out the need to integrate the law to the structural efforts and interventions to improve social support and/or reduce HIV-related stigma.

\section{References}

1. Vester A. HIV and co-infections in people who inject drugs. Geneva: WHO/Department HIV/AIDS; 2012. [cited 2014 Jan 15]. Available from: http://www.unaids.org/en/media/unaids/ contentassets/documents/pcb/2012/20120612_Annette_ Verster_presentation.pdf

2. Acharya C, Dharel N, Sterling RK. Chronic Liver Disease in the Human Immunodeficiency Virus Patient. Clin Liver Dis. 2015; 19(1): 1-22.

3. Rusakova M, Rakhmetova A, Strathdee SA. Steffanie Strathdee: "called" to HIV prevention. The Lancet . 2015; 385(9962): 20-20

4. Brasil. Ministério da Saúde -Secretaria de Vigilância em Saúde- Departamento de DST, Aids e Hepatites Virais. Boletim Epidemiológico HIVIAIDS. Ano II, $1^{\circ}$ Ed. Brasília: Ministério da Saúde, 2013; 1-64.

5. Rizzardini G, Bonfanti P, Carenzi L, Coen M, Orlando G, Di Matteo $S$ et al. Cost-effectiveness analysis of HIV treatment in the clinical practice of a public hospital in northern Italy. Ther Clin Risk Manag. 2012; 8: 377-384.

6. Trapero-Bertran M, Oliva-Moreno J. Economic impact of HIV/ AIDS: a systematic review in five European countries. J Internet Serv Appl. 2014; 4(1): s. p.

7. a. Brasil. Ministério da Saúde. Medicamento 3 em 1 começa a ser distribuído em todo o país. [Acess 21 January 2015]. Available: http://portalsaude.saude.gov.br/index.php/cidadao/ principal/agencia-saude/16218-medicamento-3-em-1-comecaa-ser-distribuido-em-todo-o-pais

8. Menezes VM , Nery JAC, Sales AM, Miranda A, Galhardo MCG, Bastos Fl et al. Epidemiological and clinical patterns of 92 patients co-infected with HIV and Mycobacterium leprae from Rio de Janeiro State, Brazil. Trans R Soc Trop Med Hyg. 2014. 108(2): pp. 63-70.

9. Wagner GJ, Gosh-Dastidar B, Slaughter M, Akena D, Nakasujja $\mathrm{N}$, Okello $\mathrm{E}$ et al. The Role of Depression in Work-Related Outcomes of HIV Treatment in Uganda. Int J Behav Med. 2014; 21(6): 946-955.

10. Giorgio LC, Vincenzo C, Antonio Di B, Sergio Di M, Claudio V, Pierluigi V. Cost-effectiveness analysis of initial HIV treatment under Italian guidelines. Clinicoecon Outcomes Res. 2011; 3 : 197-205.

11. b. Brasil. Justiça Federal. Turma Nacional de Uniformização dos Juizados Especiais. 2015 [Acess 22 January 2015]. Available: http://www.cjf.jus.br/cjf/tnu

12. a. Brasil. Conselho Nacional de Justiça. Súmula $n^{\circ} 78$. Comprovado que o requerente de benefício é portador do vírus HIV, cabe ao julgador verificar as condições pessoais, sociais, econômicas e culturais, de forma a analisar a incapacidade em sentido amplo, em face da elevada estigmatização social da doença. 2014. [Acess 22 January 2015]. Available: https://www2.jf.jus.br/phpdoc/virtus/sumula.php?nsul=78\&PH PSESSID=tbd66ginqnvj6tvj201 mrqn582 
13. c. Brasil. Tribunal Regional Federal da $5^{\circ}$ Região -Portal da Justiça Federal da $5^{\circ}$ Região, 2015. [Acess 22 January 2015]. Available: http://www.trf5.jus.br/

14. Brasil. Constituição (1988). Constituição da República Federativa do Brasil. Brasília, DF: Senado Federal: Centro Gráfico, 1988, 292p.

15. Oliva J. Labour participation of people living with HIVIAIDS in Spain. Health Econ. 2010; 19(4): 491-500

16. Jong E, Oudhoff LA, Epskamp C, Wagener MN, van Duijn M, Fischer $S$ et al. Predictors and treatment strategies of HIV-related fatigue in the combined antiretroviral therapy era. AIDS. 2010; 24(10): 1387-405.

17. Wagener M, Opstal S, Miedema H, Brandjes D, Dahmen R, Gorp E, Roelofs, P. Employment-Related Concerns of HIVPositive People in the Netherlands: Input for a Multidisciplinary Guideline. J Occup Rehabil. 2014; 24(4): 790-7.

18. Wu ES, Rothbard A, Blank MB. Using Psychiatric Symptomatology to Assess Risk for HIV Infection in Individuals with Severe Mental Illness. Community Ment Health J. 2011; 47(6): 672-678.

19. Arseniou S, Arvaniti A, Samakouri M. HIV infection and depression. Psychiatry Clin Neurosci. 2014; 68(2): 96-109.

20. b. Brasil. Medida provisória n 664, de 30 de dezembro de 2014. Altera as Leis no 8. 213, de 24 de julho de 1991, n 10. 876, de 2 junho de 2004, n 8. 112, de 11 de dezembro de 1990, ea Lei n 10. 666, de 8 de maio de 2003. Diário Oficial da República Federativa do Brasil, Poder Executivo, Brasília, DF, 2014. [Acess 14 Febraury 2015]. Available: http://www.planalto.gov.br/ ccivil_03/_Ato2011-2014/2014/Mpv/mpv664. htm

21. Grabmeier-Pfistershammer K, Rieger A, Schroeck T, Schlag M. Late versus non-late presentation of HIV/AIDS: an economic impact analysis. J Int AIDS Soc. 2010; 13(Suppl 4): P236.

\section{Comment on this article:}

\section{(f) [in is $\mathbf{S}$ ?}

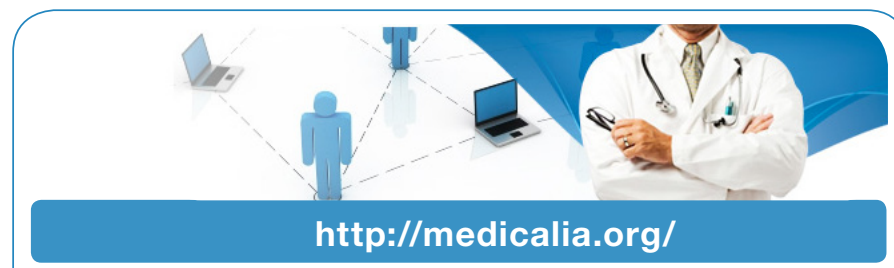

Where Doctors exchange clinical experiences, review their cases and share clinical knowledge. You can also access lots of medical publications for free. Join Now!

\section{Publish with iMedPub}

http://www.imed.pub

International Archives of Medicine is an open access journal publishing articles encompassing all aspects of medical science and clinical practice. IAM is considered a megajournal with independent sections on all areas of medicine. IAM is a really international journal with authors and board members from all around the world. The journal is widely indexed and classified Q1 in category Medicine. 